\title{
特集「ランドスケープ・プランニングの現在」にあたって
}

\section{Special Issue on Landscape Planning: Where we are and heading to}

\author{
特集企画担当編集委員 横張 真 ${ }^{*}$ 入江 彰昭** \\ Makoto YOKOHARI, Teruaki IRIE
}

近年の情報ネットワークの急速な発達・普及により, 情 報はいとも簡単に国境を越え，世界の隅々にまで瞬時に到 達する。それはあたかも，情報を発信した主体およびその 価値観が世界を席巻するかのような感覚を人々にもたらす。 しかし一方, 気候や地勢などの自然条件, 歴史, 文化さら には宗教に裏打ちされた各地域固有の価値観は, 世界各地 に今なお厳然と存在し続けている。それどころか, 情報の グローバルな共有化が進むなかで, 地域間での価值観の相 違はむしろ鮮明化し, 対立へと発展する傾向が強まりつつ あるとすらいえる。2001年 9 月 11 日にアメリカで発生し た同時多発テロはこうした時代を象徴するものだろう。 20 世紀, とくにその最後の 10 余年は, アメリカ型資本主 義を至上の価值観とするなかで世界が突き進んだ時代であっ た。21 世紀は, そうした幻想から覚醒した世界が, 多様 なローカリティを尊重するという理念を共有しつつ, グロー バル・スケールでの新たな普遍的価值観の構築を目指す時 代と特徴づけられよう。

地域固有の自然, 歴史, 文化を反映した多様なローカリ ティを尊重する普遍性。本特集において武内やアリフィン らをはじめ多くの著者がそろって指摘するように，この問 いは，とりあなおさずランドスケープ・プランニング分野 が目指してきた方法論の根幹をなすものに他ならない。八ー レンによれば, ランドスケープは「文化, 生態, 経済シス テムの有機的な関係性の結果として生じる, 視覚的に知覚・ 理解できる表象」と定義される, きわめてローカルかつヴァ ナキュラーな存在である。20世紀におけるランドスケー プ・プランニングの歴史は，スタイニッッが指摘するよう に，そうしたランドスケープのあつ本質的な特性を前提と しながら，その先に普遍的な計画の方法論を構築しようと したところにあった。「多様性を内包した普遍性」が 21 世 紀のキーワードのひとつとされるなか, ランドスケープ・ プランニングの目指してきた方向は，時代の潮流と同じべ クトル上にある。

ローカリティの尊重は, 地域に暮らす人々の意向の尊重 をあ意味する。プランニングという行為は従来, ともする
とプランナーや行政担当者といった専門家の手に一元的に ゆだねられてきた。しかし，社会のあらゆる局面に打ける 情報開示之市民の意志決定への参画が求められるなか, ラ ンドスケープ・プランニング分野においても，市民に対す る明確な情報の開示と, その意志の的確な把握および計画 への反映が求められている。本特集においてスタイニッッ が紹介する計画手法は,こうした時代の要求に対する明確 な回答のひとつといえる。

一方, 20 世紀におけるランドスケープ・プランニング の重要な流れのひとつに, 60 年代末から 70 年代初頭にド イッやアメリカで端を発したエコロジカル・プランニング がある。森本も指摘するように，マクハーグらを源流とす る地域の生物・生態系に着目したプランニングの方法論は, 一方では地域レベルでの環境問題の顕在化や生物多様性の 保全に対する社会的コンセンサスの高まり, 他方では学術 的な基礎としての景観生態学分野の成熟を受けて, ランド スケープ・プランニングの根幹をなす方法論のひとつへと 発展している。

以上のように，ランドスケープ・プランニングとくに 20 世紀後半のそれは, 「多様性を内包した普遍性」「一般 市民への情報開示と参画機会の提供」「生物・生態系の保 全」などを共通課題とするなかで, 方法論の発展・深化が 図られてきた。こうした流れは一方で，計画そのものより あむしろ計画立案プロセスにプランニングの目的があるか のような風潮を生んだ。しかし, いかにプロセス重視が時 代の趨勢とはいえ，ランドスケープ・プランニングのアイ デンティティは, 社会や環境に対する様々な要求を, デザ インという行為を通じて止揚し, ある空間の形態として結 実させるところにある。下田は, 北海道旭川市における事 例を通じて，こうしたランドスケープ・プランニングの実 際を伝えている。

本特集は，日本のみならずアメリカ，ドイッ，インドネ シアからの寄稿を得るなかで, こうしたランドスケープ・ プランニングの “現在”を鮮明に描写するものとなってい るものと思う。

*筑波大学社会工学系 **東京農業大学短期大学部 